\title{
Comparison of diffusion tube-measured nitrogen dioxide concentrations at child and adult breathing heights: who are we monitoring for?
}

\author{
Alex Rowell ${ }^{1} \cdot$ Michael E. Terry $^{2} \cdot$ Michael E. Deary $^{1}$ (D) \\ Received: 9 July 2020 / Accepted: 13 August 2020 / Published online: 25 August 2020 \\ (C) The Author(s) 2020
}

\begin{abstract}
Many towns and cities use passive samplers (diffusion tubes) to monitor nitrogen dioxide $\left(\mathrm{NO}_{2}\right)$ concentration. However, literature studies have shown large horizontal and vertical concentration gradients for diffusion tubes placed over short distances, raising concerns over the representativeness of monitoring locations. This study examines variations in $\mathrm{NO}_{2}$ concentrations with height at two roadside locations along a busy urban road in Newcastle upon Tyne (UK) over an 8-month period. $\mathrm{NO}_{2}$ concentrations were passively monitored at building facades (approximately $7.0 \mathrm{~m}$ from the roadside) at heights of $0.7 \mathrm{~m}, 1.7 \mathrm{~m}$ and $2.7 \mathrm{~m}$ to replicate child breathing height in prams and buggies, adult breathing height and the Newcastle City Council sampling height (for 2017), respectively. Paired $t$ tests indicated that $\mathrm{NO}_{2}$ concentrations were significantly lower at $2.7 \mathrm{~m}(4.7 \%$ lower, $n=16, p=0.001)$ and $1.7 \mathrm{~m}(7.1 \%$ lower, $n=14, p=0.007)$ compared with those at $0.7 \mathrm{~m}$. There was no statistically significant difference between $\mathrm{NO}_{2}$ concentrations measured at $2.7 \mathrm{~m}$ and $1.7 \mathrm{~m}$, indicating that UK local authority practice of placing diffusion tubes at higher than adult breathing height does not result in underreporting of $\mathrm{NO}_{2}$ concentrations for regulatory purposes. The results have clear public health implications as they provide evidence that young children, in an urban setting and close to busy roadways, may be exposed to higher $\mathrm{NO}_{2}$ concentrations compared with adults in the same location. We have shown that such differences might not be adequately reflected in the monitoring data from municipal authorities.
\end{abstract}

Keywords Nitrogen dioxide $\left(\mathrm{NO}_{2}\right) \cdot$ Palmes-type diffusion tubes · Passive sampling · Child and adult breathing height · Vertical fall-off in concentration

\section{Introduction}

Elevated traffic-derived nitrogen dioxide $\left(\mathrm{NO}_{2}\right)$ concentrations in urban areas have been linked to increased incidences of both mortality and disease (Atkinson et al. 2018; Committee on the Medical Effects of Air Pollutants 2018; Mills et al. 2016; WHO 2006). Of particular concern are the

Electronic supplementary material The online version of this article (https://doi.org/10.1007/s11869-020-00909-4) contains supplementary material, which is available to authorized users.

Michael E. Deary

michael.deary@northumbria.ac.uk

1 Department of Geography and Environmental Sciences, Faculty of Engineering and Environment, Northumbria University, Ellison Building, Newcastle upon Tyne NE1 8ST, UK

2 Public Safety, Regulation and Development, Newcastle City Council, Civic Centre, 7th Floor, Barras Bridge, Newcastle upon Tyne NE1 8QH, UK adverse health effects of $\mathrm{NO}_{2}$ on children (Esposito et al. 2014; Favarato et al. 2014; Gaffin et al. 2018), given that many schools are located in areas that breach air quality guidelines for $\mathrm{NO}_{2}$ (Guerriero et al. 2016; Salonen et al. 2019). To help protect the public against the health effects of $\mathrm{NO}_{2}$, the World Health Organization (WHO) has set guideline values of $40 \mu \mathrm{g} \mathrm{m}^{-3}$ and $200 \mu \mathrm{g} \mathrm{m}^{-3}$ for long-term (annual) and shortterm (1-h) exposures respectively. The European Union and the UK use the same values (Beckwith et al. 2019). Nevertheless, there is evidence that $\mathrm{NO}_{2}$ is associated with health effects at concentrations that are well below the guideline values, even as low as $5 \mu \mathrm{g} \mathrm{m}^{-3}$ (Committee on the Medical Effects of Air Pollutants 2018).

Recent UK government statistics show that road sources contribute $34 \%$ of the total emissions of nitrogen oxides $\left(\mathrm{NO}_{x}\right)$ in the UK, with energy generation; domestic and industrial sources; and other transport sources contributing 22\%, $19 \%$ and $17 \%$ of the total respectively (DEFRA 2019a). At locations immediately adjacent to roads, $80 \%$ of the total $\mathrm{NO}_{x}$ emissions are contributed from road sources (DEFRA 
2019a). The $\mathrm{NO}_{2}$ component of the total $\mathrm{NO}_{x}$ emissions comprises primary and secondary sources. Primary $\mathrm{NO}_{2}$ is the fraction of $\mathrm{NO}_{x}$ emitted from a car exhaust that is already in the form of $\mathrm{NO}_{2}$. Over the last two decades, the fraction of $\mathrm{NO}_{x}$ emitted in the form of primary $\mathrm{NO}_{2}$ has increased significantly, from below 0.1 for vehicles manufactured before 1998, to well over 0.3 more recently (Carslaw et al. 2019), with some studies quoting as high as 0.7 (Keuken et al. 2012).

Increased numbers of diesel vehicles on the road, with their widespread use of catalytic emission control technologies, are largely responsible for the increase in the fraction of $\mathrm{NO}_{x}$ released as primary $\mathrm{NO}_{2}$ from car exhausts (Carslaw et al. 2019). Emission control by techniques such as selective catalytic reduction (SCR) oxidises NO to $\mathrm{NO}_{2}$, which is then used to oxidise the incomplete combustion products produced by the engine, i.e. $\mathrm{CO}$, hydrocarbons and particulate matter, thus reducing the emission of these harmful pollutants and also increasing the amount of $\mathrm{NO}_{2}$ released (Carslaw et al. 2019). Other emission control technologies include lean $\mathrm{NO}_{x}$ traps (LNT), where $\mathrm{NO}_{x}$ is reduced to ammonia and water; LNT tends to produce higher $\mathrm{NO}_{2}$ emissions than SCR (Carslaw et al. 2019). Once emitted from the vehicle exhaust, NO that has not been oxidised reacts very quickly with tropospheric ozone to produce secondary $\mathrm{NO}_{2}$ (Clapp and Jenkin 2001), with a large proportion of this reaction thought to occur on the road, over a duration of a few seconds (Yang et al. 2018). Nevertheless, $\mathrm{NO}_{x}$ emissions from vehicles are reducing as cleaner vehicles enter the overall vehicle stock (Carslaw et al. 2019; Keuken et al. 2012).

Municipal authorities monitor $\mathrm{NO}_{2}$ concentrations using a combination of instrumental and passive methods. Instrumental techniques, such as the reference method of chemiluminescence (Clapp and Jenkin 2001), allow accurate and precise determination of $\mathrm{NO}_{2}$ concentrations, with a high temporal resolution. Nevertheless, the high cost of such systems tends to restrict their geographical coverage (Pannullo et al. 2015). Passive techniques, such as Palmes-type diffusion tubes, allow a much more extensive spatial monitoring resolution. However, the requirement that the tubes be exposed for several weeks means that they are suitable only for monitoring against long-term ambient standards (exceedances of 1-h standards can be implied if annual average concentrations at diffusion tube locations exceed $60 \mu \mathrm{g} \mathrm{m}^{-3}$ (DEFRA 2016; Laxen and Marner 2003)). Diffusion tubes are also less precise than instrumental techniques and may have inherent biases (Heal et al. 2019).

Notwithstanding concerns over the performance of diffusion tubes, municipal authorities in many countries use them as an essential component of the local air quality management (LAQM) process (AEA Energy and Environment 2008). Typically, exposure of the tubes occurs over 4- or 5-week blocks (AEA Energy and Environment 2008) before being replaced, allowing $\mathrm{NO}_{2}$ determinations at monthly and yearly resolution.

UK Government guidance on the siting of diffusion tubes lists the following specific categories of site: kerbside (within $1 \mathrm{~m}$ of the kerb), roadside (between 1 and $5 \mathrm{~m}$ from the kerb edge, though in some circumstances, up to $15 \mathrm{~m}$ (DEFRA 2016)) and urban or suburban background sites (greater than $50 \mathrm{~m}$ from main roads) (AEA Energy and Environment 2008). The diffusion tubes are mounted on street furniture or building facades, as appropriate, with spacers used to ensure unimpeded airflow around the tube (AEA Energy and Environment 2008). Diffusion tube monitoring strategies are used to evaluate the performance of air quality management plans and will typically utilise dozens of diffusion tube locations across a city. For example, Newcastle City Council (NCC), in 2018, used 53 diffusion tube locations, as well as four automatic monitoring stations that were also capable of measuring $\mathrm{NO}_{2}$ (Newcastle City Council 2019). Having such large numbers of monitoring locations reporting $\mathrm{NO}_{2}$ concentrations year-on-year provides the spatial resolution needed to assess the effectiveness of air quality improvement measures.

Nevertheless, there is much literature debate about the variations in $\mathrm{NO}_{2}$ and other pollutant concentrations over distances as short as several metres, and the implications that this might have for representative siting of diffusion tube locations (Amato et al. 2019; Beckwith et al. 2019; Borge et al. 2016; Pannullo et al. 2015; Vardoulakis et al. 2011). For example, Borge et al. (2016) found $\mathrm{NO}_{2}$ gradients as high as $2 \mu \mathrm{g} \mathrm{m}^{-3} \mathrm{~m}^{-1}$ during a high spatial resolution monitoring survey at a busy roundabout in Madrid. Significant temporal variations in $\mathrm{PM}_{10}$ were also observed (as high as $55 \mu \mathrm{g} \mathrm{m}^{-3} \mathrm{~min}^{-1}$ ). Similarly, in a diffusion tube survey carried out in York, UK, Beckwith et al. (2019) found significant differences in $\mathrm{NO}_{2}$ concentrations between road stretches that were associated with acceleration, queuing or cruising. As well as the position of the monitoring location along a road with respect to junctions and pedestrian crossings etc., there is also the question of the fall-off in $\mathrm{NO}_{2}$ concentrations with distance from the kerb and the implications that this has for the reporting of representative exposure concentrations. The rate of fall-off is often reported as fitting an exponential equation (Kenagy et al. 2016) but is very much dependent on the local building infrastructure, such as the presence of street canyons (Amato et al. 2019; Borge et al. 2016). Consequently, 'halving distances' for $\mathrm{NO}_{2}$ concentrations have been reported to range from $25 \mathrm{~m}$ ( $\pm 35 \mathrm{~m} \mathrm{sd}$ ) for Barcelona (Amato et al. 2019) to over $100 \mathrm{~m}$ for Birmingham (Vardoulakis et al. 2011) and York (Beckwith et al. 2019). Of more relevance to the current study is the observation by Vardoulakis et al. (2011) that the annual mean $\mathrm{NO}_{2}$ concentrations in Birmingham were $21 \%$ higher for lamppost mounted diffusion tubes compared with those attached $5 \mathrm{~m}$ away on building facades. 
As well as considerations over the spatial positioning of $\mathrm{NO}_{2}$ monitors, the height at which they are mounted has also been shown to have a significant influence on the reported $\mathrm{NO}_{2}$ concentration (Amato et al. 2019; Barratt et al. 2018; Cheong et al. 2012; Eeftens et al. 2019; Kenagy et al. 2016; Kohler et al. 2005; Laxen and Noordally 1987; Monn et al. 1997; Sajani et al. 2018; Scottish Government 2015; Vardoulakis et al. 2011). Most of the literature studies that have examined $\mathrm{NO}_{2}$ concentration fall-off with height have done so at different heights on multi-storey buildings, allowing an assessment of risk for residents due to pollution from the busy roads below. In most of the studies, a significant reduction in $\mathrm{NO}_{2}$ concentration is observed at the higher heights, ranging from $11 \%$ (Sajani et al. 2018) to $40 \%$ (Monn et al. 1997) for monitors placed at approximately $20 \mathrm{~m}$ in comparison with ground level. Nevertheless, one such study in Singapore found a more complex relationship between height and $\mathrm{NO}_{2}$ concentrations, with the middle floors of a 22-storey building recording the highest $\mathrm{NO}_{2}$ concentrations (16\% higher at $17.5 \mathrm{~m}$ vs ground level, and then falling with increasing height thereafter) (Cheong et al. 2012). This unusual relationship was possibly due to the presence of a dense tree canopy between the road source and the building. Other factors that significantly affect the magnitude of the falloff in $\mathrm{NO}_{2}$ concentrations with height include seasonal effects (Eeftens et al. 2019; Monn et al. 1997; Sajani et al. 2018) street infrastructure, particularly street canyons (Amato et al. 2019; Vardoulakis et al. 2011), and distance from the kerb (Kenagy et al. 2016).

For the present study, we are interested in the near-ground relationship between $\mathrm{NO}_{2}$ concentration and height, i.e. the difference in concentration at breathing heights of a child in a buggy and that of an adult. The motivation for this study is the varying practice across the UK concerning the $\mathrm{NO}_{2}$ monitoring heights used by municipal authorities and how these relate to the exposure of sensitive receptors. Ideally, diffusion tubes should be placed at 'breathing height', to represent the accurate exposure of the public to $\mathrm{NO}_{2}$. Nevertheless, UK guidance recommends that diffusion tubes be placed at heights of between 2 and $4 \mathrm{~m}$ to alleviate problems with theft and damage (AEA Energy and Environment 2008; Kenagy et al. 2016). In Newcastle upon Tyne, UK, where the current study is located, diffusion tubes used by NCC were positioned at the height of $2.7 \mathrm{~m}$ above ground in 2017, though this changed to $2.5 \mathrm{~m}$ in 2018 (Newcastle City Council 2018; Newcastle City Council 2019). Therefore, an adult at an average breathing height of $1.7 \mathrm{~m}$ (Kenagy et al. 2016) will experience $\mathrm{NO}_{2}$ concentrations approximately $1 \mathrm{~m}$ below what was being monitored and reported by NCC for 2017; this will be the case for many local authority areas across the UK. The official guidance acknowledges that tubes placed at heights above the breathing zone may 'underestimate the actual concentrations to which the public are exposed' (AEA
Energy and Environment 2008). The average breathing height of children ranges from 0.7 to $1.5 \mathrm{~m}$ (Rivas et al. 2016), whereas children in prams and strollers have breathing heights of approximately $0.55 \mathrm{~m}$ and $0.85 \mathrm{~m}$ respectively (Sharma and Kumar 2018). Therefore, children will experience $\mathrm{NO}_{2}$ concentrations at heights that are as much as $2 \mathrm{~m}$ below what is being monitored and reported by NCC.

In this paper, we seek to examine the differences in measured $\mathrm{NO}_{2}$ concentrations as a function of height $(0.7 \mathrm{~m}, 1.7 \mathrm{~m}$ and $2.7 \mathrm{~m}$ ) at two separate roadside locations in the UK city of Newcastle upon Tyne. The study arose from an opportunity to incorporate additional sampling locations into the annual diffusion tube monitoring programme operated by NCC. Although such studies have been carried out in the past, notably that of Kenagy et al. (2016), who studied differences between $\mathrm{NO}_{2}$ concentrations at adult and child breathing height at roadside locations in Edinburgh, our study differs in that it is carried out at a greater distance from the road (the façade of the buildings), and for an extended period of time (8 months) and therefore for a wider range of meteorological conditions.

\section{Methodology}

The study was carried out in Heaton, a suburb of Newcastle upon Tyne, UK, approximately $3 \mathrm{~km}$ from the city centre. Heaton is a residential area with two primary schools, multiple shopping streets and a light railway station (part of the Tyne and Wear Metro system). We selected two locations along Chillingham Road (UK road reference: A188), which is the main shopping street for the area and has previously been identified by NCC as a 'hotspot' area with regard to air pollution and $\mathrm{NO}_{2}$ concentrations. Between 2008 and 2010, NCC carried out air quality monitoring, using diffusion tubes, at four locations along Chillingham Road; however, annual mean concentrations were found to be below the EU, and UK obligatory limit of $40 \mu \mathrm{g} \mathrm{m}^{-3}$ and so the monitoring was discontinued. In recent years, traffic volumes have increased, with an annual average daily traffic flow of 15,015 vehicles in 2018 , representing an increase of 5\% since 2008. The composition is $82 \%$ cars and taxis, $15 \%$ light goods vehicles, $1.2 \%$ buses and $1.2 \%$ heavy goods vehicles (Department for Transport 2020). There are several pedestrian crossing and traffic-lighted junctions that cause traffic to build up in stretches along the road.

Site 1 (X 427052, Y 566421) is situated at the northern end of Chillingham Road (see Fig. 1), approximately $30 \mathrm{~m}$ from Ravenswood Primary School. The site is positioned approximately $75 \mathrm{~m}$ from the Coast Road (A1058) roundabout, which causes frequent speed changes. The site is a 2-storey endterraced business premises. NCC previously monitored the same site between 2008 and 2010. 


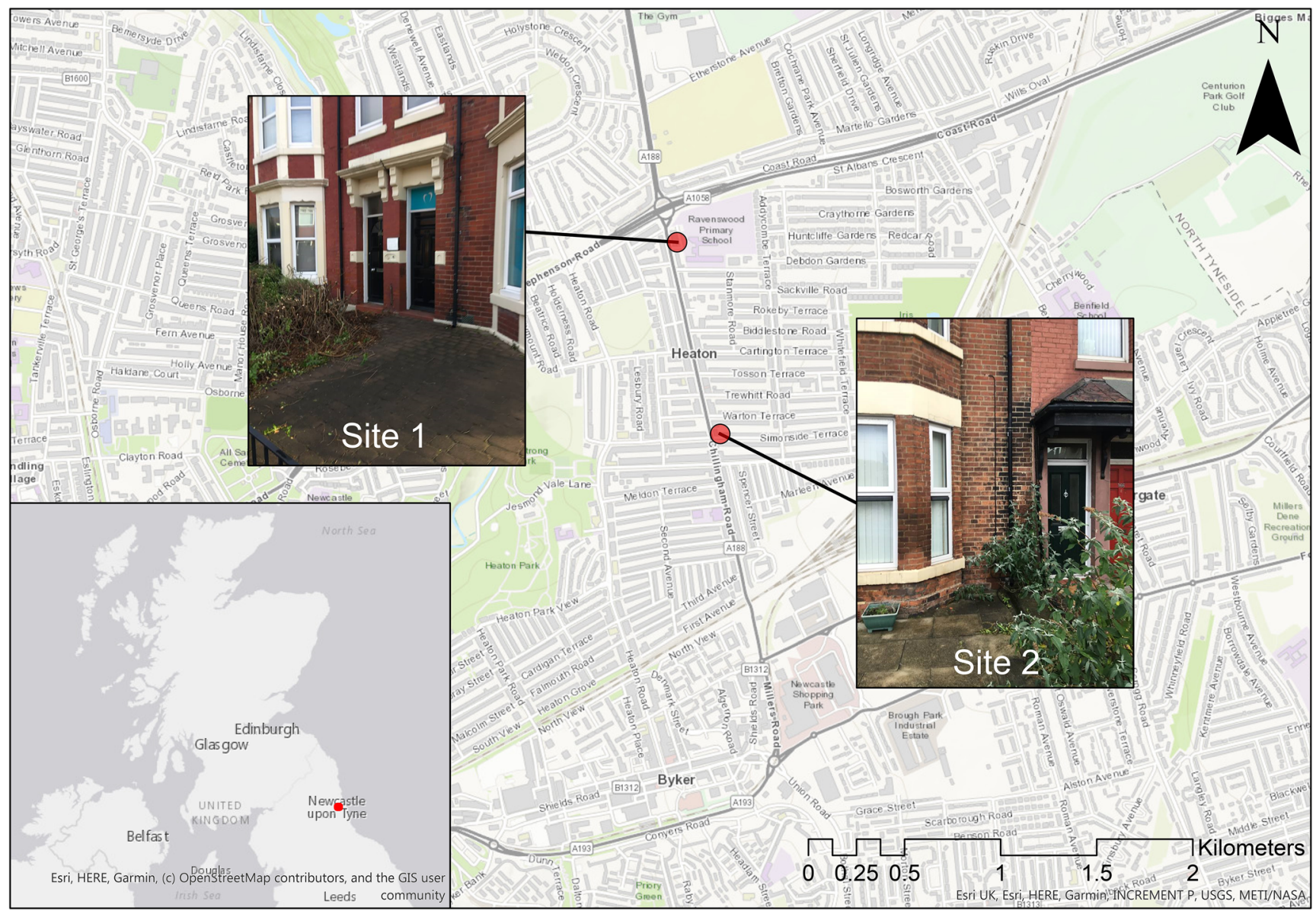

Fig. 1 Location of the monitoring sites in Newcastle upon Tyne, UK

Site 2 (X 427209, Y 565727) is situated at the southern end of Chillingham Road (see Fig. 1), approximately $85 \mathrm{~m}$ from Chillingham Road Primary School and approximately $375 \mathrm{~m}$ from Chillingham Road Metro station. The site is positioned next to a busy T-junction and a pedestrian crossing which creates stop-start and idling traffic. The site is a 2-storey terraced residential property and has several business premises in close proximity. NCC previously monitored at a location $25 \mathrm{~m}$ from the site between 2008 and 2010.

Monitoring at the two sites was carried out with Palmestype $\mathrm{NO}_{2}$ diffusion tubes in accordance with UK guidance (AEA Energy and Environment 2008; DEFRA 2016). The study was carried out as part of the overall monthly NCC diffusion tube monitoring programme.

Diffusion tubes use the principle of molecular diffusion to determine $\mathrm{NO}_{2}$ concentrations (AEA Energy and Environment 2008). When deployed, the cylindrical tubes are positioned vertically with one capped end (top) and one uncapped end (bottom) (see Fig. 2). Mass transfer occurs as gas molecules diffuse from an area of high concentration (uncapped end) to an area of low concentration (capped end) (AEA Energy and Environment 2008). The capped end contains two stainless steel grids coated in triethanolamine (TEA) to absorb $\mathrm{NO}_{2}$ directly from the air (AEA Energy and Environment 2008).

The tubes were mounted at heights of $0.7,1.7$ and $2.7 \mathrm{~m}$ to replicate child breathing height, adult breathing height (Department for Transport 2020) and NCC sampling height

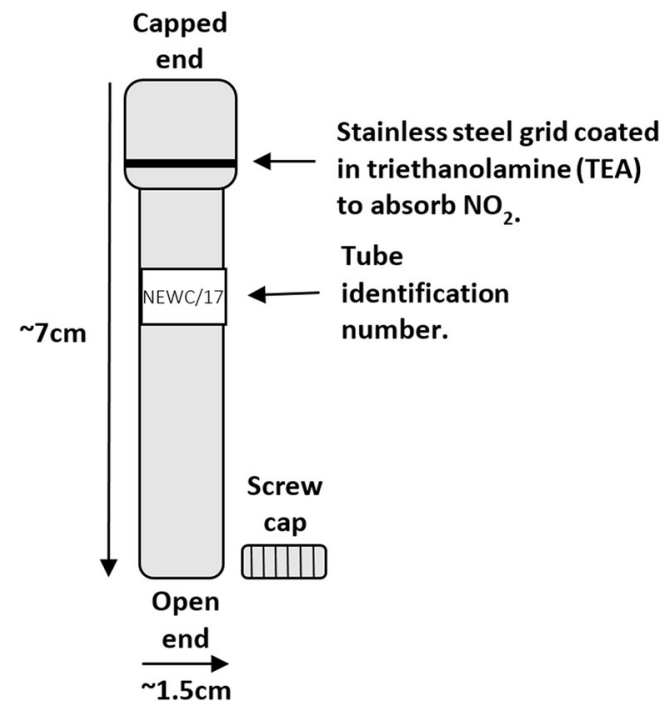

Fig. 2 Schematic of a diffusion tube 
(for 2017), respectively. Drainpipes located approximately $7 \mathrm{~m}$ from the roadside were used for mounting purposes as suitable pieces of 'street furniture'. A spacer block measuring approximately $5 \mathrm{~cm}$ was placed between the tubes and the mounting surface to allow the open-ended tube to be exposed to freely circulating air. The tubes and spacer blocks were fixed to the drainpipes using a cable tie. The tubes were deployed in accordance with the diffusion tube calendar supplied by DEFRA (DEFRA 2019b). The exposure periods consisted of 4- or 5-week blocks (i.e. 28 or 35 days) over 9 months (July 2018 to February 2019 inclusive; the start and end dates of the exposure months were on Wednesdays). The tubes were changed on specific dates, as defined by the diffusion tube calendar ( \pm 2 days).

The tubes were labelled with a unique sequentially numbered ID for logging purposes and each batch was placed in an airtight bag before and after exposure periods. The tubes were stored in a refrigerator and returned to SOCOTEC UK Limited (formerly ESG) for laboratory analysis in accordance with the standard guidance (AEA Energy and Environment 2008). At the laboratory, a colorimetric analysis technique was performed using a continuous flow auto-analyser (CFA) to determine $\mathrm{NO}_{2}$ concentrations by the quantification of the colour change in comparison with that produced by a known standard.

Diffusion tubes tend to under- or over-estimate $\mathrm{NO}_{2}$ concentrations for a variety of reasons, including variable wind flow at the tube opening, within-tube reaction of nitric oxide with ozone, and incomplete conversion of $\mathrm{NO}_{2}$ to nitrite in warm, sunny, low humidity conditions (RH $<75 \%$ ) (AEA Energy and Environment 2008; Heal et al. 2019). As a result, local authorities are required to quantify the bias of their diffusion tube measurements and apply an appropriate bias adjustment factor. NCC carry out their own co-location studies in which the accuracy of the diffusion tubes is verified by exposure in conjunction with an automatic chemiluminescence analyser located at the Automatic Urban and Rural Network (AURN) station at St Mary's Place (Newcastle City Council 2019). The NCC local bias adjustment factor was 0.90 for 2018/2019 (personal communication from NCC).

During this study, less than 1 year of $\mathrm{NO}_{2}$ diffusion tube data was obtained, and so we applied the standard seasonal adjustment approach used by local authorities in the UK (DEFRA 2016). Equation 1 was used to carry out the adjustment, where $\left[\mathrm{NO}_{2}\right]_{\text {Raw }}$ is the unadjusted $\mathrm{NO}_{2}$ concentration; $\left[\mathrm{NO}_{2}\right]_{\mathrm{SA}}$ is the seasonally adjusted $\mathrm{NO}_{2}$ concentration; [AURN $N_{\text {Year] }}$ is the annual average $\mathrm{NO}_{2}$ concentration measured by the chemiluminescence method at the Newcastle City Centre (Background Urban) for the year beginning July 2018; and [AURN ${ }_{\text {Period }}$ ] is the corresponding concentration for the 8-month sampling period of the study. The yearly and period averages were $30.22 \mu \mathrm{g} \mathrm{m}^{-3}$ and $30.85 \mu \mathrm{g} \mathrm{m}^{-3}$ respectively, giving a quotient in Eq.1 of 0.980 .

$\left[\mathrm{NO}_{2}\right]_{\mathrm{SA}}=\left[\mathrm{NO}_{2}\right]_{\text {Raw }} \frac{\left[\mathrm{AURN}_{\text {Year }}\right]}{\left[\mathrm{AURN} \mathrm{N}_{\text {Period }}\right]}$

\section{Results and discussion}

\section{Trends in diffusion tube concentrations}

The trends for the raw monthly $\mathrm{NO}_{2}$ concentrations at the three heights, for the two sites, are shown in Fig. 3, and a summary of the average concentration over the 8-month sampling period is shown in Table 1. In addition, Table 1 shows the bias-adjusted concentration at $2.7 \mathrm{~m}$ (the standard NCC sampling height for diffusion tube measurements for 2017) for the entire sampling period (applying a bias adjustment factor of 0.9 , obtained from a co-location study), together with a seasonally adjusted concentration for the year beginning July 2018, as described in the methodology. The bias- and seasonally adjusted $\mathrm{NO}_{2}$ concentrations are both well below the $40 \mu \mathrm{g} \mathrm{m}^{-3} \mathrm{EU}$ limit. The concentration of $\mathrm{NO}_{2}$ at site 1 is approximately $5 \mathrm{\mu g} \mathrm{m}^{-3}$ lower than that at site 2 . Both sites are
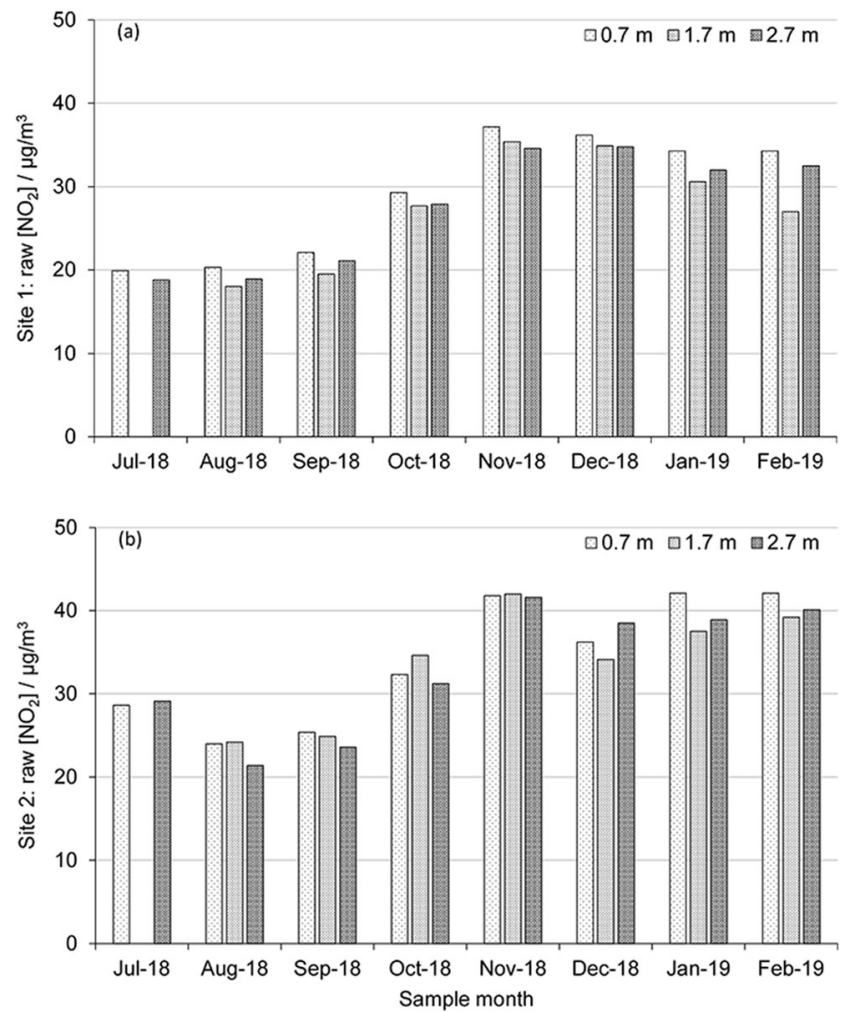

Fig. 3 Monthly trends in $\mathrm{NO}_{2}$ concentration measured by diffusion tubes at two different locations: (a) site 1 and (b) site 2. Three height locations were monitored at each location, as specified in the legend. All measurements are raw data, as received from the laboratory, and are uncorrected for bias or seasonal effects 
Table $1 \mathrm{NO}_{2}$ concentrations calculated from the 7- or 8-month monitoring period at each height. The unadjusted mean refers to the raw data, as received from the laboratory; the bias-adjusted mean has been corrected using a factor of 0.9 , determined from a co-location study and the bias/seasonally adjusted concentration has been further adjusted to account for seasonal effects of the monitoring period, as described in the text

\begin{tabular}{llllll}
\hline $\begin{array}{l}\text { Site } \\
(\mathrm{m})\end{array}$ & $\begin{array}{l}\text { Height } \\
\text { period } \\
(\text { months })\end{array}$ & $\begin{array}{l}\text { Unadjusted } \\
\left.\text { mean } \mathrm{NO}_{2}\right]\end{array}$ & $\begin{array}{l}\text { Bias- } \\
\text { adjusted } \\
{\left[\mathrm{NO}_{2}\right]} \\
\left(\mu \mathrm{g} \mathrm{m}^{-3}\right)\end{array}$ & $\begin{array}{l}\text { Bias and } \\
\text { seasonally } \\
\text { adjusted }\left[\mathrm{NO}_{2}\right] \\
\left(\mu \mathrm{g} \mathrm{m}^{-3}\right)\end{array}$ \\
\hline 1 & 0.7 & 8 & $29.20(6.90)$ & $\mathrm{n} / \mathrm{a}$ & $\mathrm{n} / \mathrm{a}$ \\
& 1.7 & 7 & $27.59(6.34)$ & $\mathrm{n} / \mathrm{a}$ & $\mathrm{n} / \mathrm{a}$ \\
& 2.7 & 8 & $27.58(6.52)$ & 24.82 & 24.32 \\
2 & 0.7 & 8 & $34.06(7.10)$ & $\mathrm{n} / \mathrm{a}$ & $\mathrm{n} / \mathrm{a}$ \\
& 1.7 & 7 & $33.79(6.35)$ & $\mathrm{n} / \mathrm{a}$ & $\mathrm{n} / \mathrm{a}$ \\
& 2.7 & 8 & $33.05(7.34)$ & 29.75 & 29.14 \\
\hline
\end{tabular}

prone to traffic build-up and stop-start traffic, though this is more significant at site 2 , given the close proximity to a $\mathrm{T}$ junction and pedestrian crossing. The general trends for monthly $\mathrm{NO}_{2}$ concentrations shown in Fig. 1 are typical of the annual European pattern of $\mathrm{NO}_{2}$ concentrations, with the highest concentrations observed in winter months due to meteorological conditions such as ground-level temperature inversions and increased use of domestic heating (Hazenkampvon Arx et al. 2004).

In Table 2, the differences between $\mathrm{NO}_{2}$ concentration at the three sampling heights are depicted as (a) the difference between the unadjusted mean values for the sampling period, taken from Table 1, and (b) the average difference for pairwise comparisons of raw monthly $\mathrm{NO}_{2}$ concentrations (both as $\mu \mathrm{g} \mathrm{m}^{-3}$ and \%). By both measures, there are differences in $\mathrm{NO}_{2}$ concentrations between the heights, with higher concentrations prevalent at the lower heights. The significance of these differences was tested using a paired sample $t$ test analysis (two-tailed) on the raw monthly $\mathrm{NO}_{2}$ concentrations from diffusion tubes for each combination of sampling heights $(2.7 \mathrm{~m}$ vs $1.7 \mathrm{~m}, 2.7 \mathrm{~m}$ vs $0.7 \mathrm{~m}$ and $1.7 \mathrm{~m}$ vs $0.7 \mathrm{~m}$ ). The $t$ tests were carried out on data from each site separately and for both sites combined. The combined analysis is justified because the distance of the diffusion tubes to the kerbside was the same for both sites $(7 \mathrm{~m})$ and the same approach was used for a similar study carried out by Kenagy et al. (2016).

For site 2, all pairwise height comparisons show that the $\mathrm{NO}_{2}$ concentration is lower at the higher of the comparison heights; however, none of the comparisons are statistically significant. For site 1 and the combined set of data, the concentration at $0.7 \mathrm{~m}$ is significantly higher than at both $1.7 \mathrm{~m}$ and $2.7 \mathrm{~m}$. However, there is no statistically significant difference in concentrations between 1.7 and $2.7 \mathrm{~m}$, i.e. between adult breathing height and the sampling height used by NCC. For the combined set of data, the difference in concentration between NCC sampling height and a child breathing height is $1.32 \mu \mathrm{g} \mathrm{m}^{-3}$, or $4.71 \%$.

\section{Comparison with other studies}

Table 3 compares a range of literature studies, both for short vertical distances, as in our case, and for those that have been conducted on tall buildings, as already discussed. Of the studies listed in Table 3, only two have investigated the variation in $\mathrm{NO}_{2}$ concentrations near to the ground (Kenagy et al. 2016; Scottish Government 2015). The significantly higher $\mathrm{NO}_{2}$ concentration measured in our study at $0.7 \mathrm{~m}$ compared with that at $2.7 \mathrm{~m}$ (site 1 and the combined data set) is in agreement with research carried out by Kenagy et al. (2016). They found that tubes placed $<5 \mathrm{~m}$ from the kerb in a busy Edinburgh street were $8.7 \%$ lower at $2.0 \mathrm{~m}$ compared with that at $0.8 \mathrm{~m}$. This same study found that tubes placed $>5 \mathrm{~m}$ from the kerb
Table 2 Differences in $\mathrm{NO}_{2}$ concentrations for each height comparison, at two different locations, and also for all data combined. Two measures of difference are calculated: firstly, the differences in the unadjusted mean value values from Table 1 and secondly, the average difference from the paired tubes for each month, from which a $p$ value is also calculated. The unadjusted mean refers to the raw data, as received from the laboratory

\begin{tabular}{|c|c|c|c|c|c|c|}
\hline Site & Comparison & $\mathrm{n}$ (months) & $\begin{array}{l}\text { Difference in unadjusted } \\
\text { mean }\left[\mathrm{NO}_{2}\right]\left(\mu \mathrm{g} \mathrm{m}^{-3}\right)\end{array}$ & $\begin{array}{l}\text { Average difference for } \\
\text { paired values }( \pm \mathrm{sd})\left(\mu \mathrm{g} \mathrm{m}^{-3}\right)\end{array}$ & $\begin{array}{l}\text { Average difference for paired } \\
\text { values }( \pm \mathrm{sd})(\%)\end{array}$ & $\begin{array}{l}\mathrm{p} \text { value for paired } \\
t \text { tests }\end{array}$ \\
\hline \multirow[t]{3}{*}{1} & $2.7 \mathrm{~m}$ vs $1.7 \mathrm{~m}$ & 7 & $-0.01(-0.04 \%)$ & $1.24(1.91)$ & $4.43(5.96)$ & 0.162 \\
\hline & $2.7 \mathrm{~m}$ vs $0.7 \mathrm{~m}$ & 8 & $-1.62(-5.87 \%)$ & $-1.63(0.53)$ & $-5.91(1.24)$ & 0.000 \\
\hline & $1.7 \mathrm{~m}$ vs $0.7 \mathrm{~m}$ & 7 & $-1.61(-5.83 \%)$ & $-2.94(1.92)$ & $-11.40(7.38)$ & 0.010 \\
\hline \multirow[t]{3}{*}{2} & $2.7 \mathrm{~m} \mathrm{vs} 1.7 \mathrm{~m}$ & 7 & $-0.74(-2.23 \%)$ & $-0.17(2.48)$ & $-1.88(7.97)$ & 0.871 \\
\hline & $2.7 \mathrm{~m}$ vs $0.7 \mathrm{~m}$ & 8 & $-1.01(-3.06 \%)$ & $-1.01(1.68)$ & $-3.66(5.50)$ & 0.157 \\
\hline & $1.7 \mathrm{~m}$ vs $0.7 \mathrm{~m}$ & 7 & $-0.27(-0.80 \%)$ & $-1.06(2.13)$ & $-2.84(5.80)$ & 0.269 \\
\hline \multirow[t]{3}{*}{1 and 2} & $2.7 \mathrm{~m}$ vs $1.7 \mathrm{~m}$ & 14 & $\mathrm{n} / \mathrm{a}$ & $0.54(2.32)$ & $1.32(7.49)$ & 0.421 \\
\hline & $2.7 \mathrm{~m}$ vs $0.7 \mathrm{~m}$ & 16 & $\mathrm{n} / \mathrm{a}$ & $-1.32(1.29)$ & $-4.71(4.27)$ & 0.001 \\
\hline & $1.7 \mathrm{~m}$ vs $0.7 \mathrm{~m}$ & 14 & $\mathrm{n} / \mathrm{a}$ & $-2.00(2.24)$ & $-7.12(7.89)$ & 0.007 \\
\hline
\end{tabular}


Table 3 Comparison of literature results for vertical differences in $\mathrm{NO}_{2}$ concentration

\begin{tabular}{|c|c|c|c|c|c|}
\hline Location & $\begin{array}{l}\text { Type and comparison } \\
\text { height range of monitors }\end{array}$ & $\begin{array}{l}\text { Distance from } \\
\text { kerb }\end{array}$ & Duration and frequency & $\begin{array}{l}\text { Findings for } \mathrm{NO}_{2} \text { (reported as higher vs lower } \\
\text { heights) }\end{array}$ & Reference \\
\hline $\begin{array}{l}\text { Newcastle } \\
\text { upon Tyne, } \\
\text { UK }\end{array}$ & $\begin{array}{l}\mathrm{DT} \text { at } 0.7 \mathrm{~m}, 1.7 \mathrm{~m} \text { and } \\
2.7 \mathrm{~m} \text { for two } \\
\text { locations }\end{array}$ & $\begin{array}{l}7 \mathrm{~m} \text { at } \\
\text { building } \\
\text { façade }\end{array}$ & $\begin{array}{l}8 \text { months, with tubes } \\
\text { changed every } 4-5 \text { weeks }\end{array}$ & $\begin{array}{l}\text { Both locations showed no significant } \\
\text { difference at } 2.7 \mathrm{~m} \text { vs } 1.7 \mathrm{~m} \text {; one location } \\
\text { and combined dataset showed that } \mathrm{NO}_{2} \\
\text { concentration was } 4.7-5.9 \% \text { lower at } 2.7 \mathrm{~m} \\
\text { vs } 0.7 \mathrm{~m} \text { and } 7.1-11.4 \% \text { lower at } 1.7 \mathrm{~m} \text { vs } \\
0.7 \mathrm{~m} \text {. Based on } 48 \text { paired comparisons ( } 2 \\
\text { locations; } 3 \text { heights; } 7 \text { months). }\end{array}$ & This work \\
\hline $\begin{array}{l}\text { Edinburgh, } \\
\text { UK }\end{array}$ & $\begin{array}{l}\text { DT at } 0.8 \mathrm{~m} \text { (child in } \\
\text { buggy) and } 2 \mathrm{~m} \text { (adult } \\
\text { breathing zone) }\end{array}$ & 0.4 to $4.7 \mathrm{~m}$ & 1 week & $\begin{array}{l}\text { 8.7\% lower at } 2.0 \mathrm{~m} \text { vs } 0.8 \mathrm{~m} \text { (for all data } \\
<5 \mathrm{~m} \text { from kerb). Based on } 84 \text { paired } \\
\text { comparisons }(<5 \mathrm{~m} \text { from kerb). }\end{array}$ & $\begin{array}{l}\text { Kenagy et al. } \\
\quad(2016)\end{array}$ \\
\hline Glasgow, UK & $\begin{array}{l}\text { AQMesh at } 0.8 \mathrm{~m} \text { (child } \\
\text { in buggy) and } 1.68 \mathrm{~m} \\
\text { (adult) }\end{array}$ & $\begin{array}{l}0 \mathrm{~m} \text { (mobile } \\
\text { monitoring } \\
\text { trolley) }\end{array}$ & $\begin{array}{l}\text { Total of } 6 \text { weekdays and two } \\
\text { weekend days, taken } \\
\text { between } 03 / 14 \text { and } 08 / 14 \\
\text { (07.00 to } 19.00)\end{array}$ & $\begin{array}{l}\text { Up to } 15 \% \text { higher at } 1.68 \mathrm{~m} \text { vs } 0.8 \mathrm{~m} \text { at busy } \\
\text { junctions; no significant differences at low } \\
\text { ambient concentrations. Based on } 61 \text { paired } \\
\text { comparisons of average hourly } \\
\text { measurements. }\end{array}$ & $\begin{array}{l}\text { Scottish } \\
\text { Governm- } \\
\text { ent (2015) }\end{array}$ \\
\hline $\begin{array}{l}\text { Birmingham, } \\
\text { UK }\end{array}$ & $\begin{array}{l}\text { DT } 2.4 \mathrm{~m} \text { to } 9.5 \mathrm{~m} \text { on } \\
\text { multi-storey buildings }\end{array}$ & $\begin{array}{l}5.5 \mathrm{~m} \\
\quad \text { (façade) }\end{array}$ & $134-5$ week periods & $\begin{array}{l}\text { 24\% lower at } 9.5 \mathrm{~m} \text { vs } 2.4 \mathrm{~m} \text { (winter, read } \\
\text { from graph). Based on mean of } 13 \mathrm{DT} \\
\text { measurements }\end{array}$ & $\begin{array}{l}\text { Vardoulakis } \\
\text { et al. } \\
\text { (2011) }\end{array}$ \\
\hline $\begin{array}{l}\text { Barcelona, } \\
\text { Spain }\end{array}$ & $\begin{array}{l}\text { DT up to } 33 \mathrm{~m} \text { on } \\
\text { multi-storey buildings }\end{array}$ & $\begin{array}{l}\text { Building } \\
\text { façade }\end{array}$ & 2-4 weeks & $\begin{array}{l}10 \% \text { lower at } 15 \mathrm{~m} \text { vs } 3 \mathrm{~m} \text {. Based on } 28 \\
\text { vertical profiles }\end{array}$ & $\begin{array}{l}\text { Amato et al. } \\
\text { (2019) }\end{array}$ \\
\hline $\begin{array}{l}\text { Basel, } \\
\text { Switzerla- } \\
\text { nd }\end{array}$ & $\begin{array}{l}\text { DT up to } 20 \mathrm{~m} \text { on } \\
\text { multi-storey buildings }\end{array}$ & $\begin{array}{l}\text { Building } \\
\text { façade }\end{array}$ & $\begin{array}{l}14 \text { day period in both winter } \\
\text { and summer }\end{array}$ & $\begin{array}{l}\text { 4.1\% lower at } 5 \mathrm{~m} \text { vs ground floor } \\
(1.8-2.9 \mathrm{~m}) \text { in winter; } 5.4 \% \text { lower at } 5 \mathrm{~m} \\
\text { vs ground floor in summer. Based on } \\
\text { exponential decay model using } \\
\text { measurements from DTs placed on } 25 \\
\text { buildings ( } N=72 \text { for winter and } 69 \text { for } \\
\text { summer with median value chosen for } \\
\text { decay constant) }\end{array}$ & $\begin{array}{l}\text { Eeftens et al. } \\
\quad(2019)\end{array}$ \\
\hline $\begin{array}{l}\text { Bologna, } \\
\text { Italy }\end{array}$ & $\mathrm{DT}, 2 \mathrm{~m}$ to $65 \mathrm{~m}$ & $\begin{array}{l}\text { Building } \\
\text { façade }\end{array}$ & $\begin{array}{l}15 \text { day period in both winter } \\
\text { and summer }\end{array}$ & $\begin{array}{l}\text { 17\% lower at } 15 \mathrm{~m} \text { vs } 2 \mathrm{~m} \text { (summer, read } \\
\text { from graph); 11\% lower at } 15 \mathrm{~m} \text { vs } 2 \mathrm{~m} \\
\text { (winter); } 39 \% \text { lower at } 65 \mathrm{~m} \text { vs } 2 \mathrm{~m} \\
\text { (summer); } 74 \% \text { lower at } 65 \mathrm{~m} \text { vs } 2 \mathrm{~m} . \\
\text { Findings based on one set of measurement } \\
\text { taken in both winter and summer }\end{array}$ & $\begin{array}{l}\text { Sajani et al. } \\
\text { (2018) }\end{array}$ \\
\hline Zurich & $\mathrm{DT}$, at $3.5 \mathrm{~m}$ and $20 \mathrm{~m}$ & $\begin{array}{l}\text { Building } \\
\text { façade }\end{array}$ & $\begin{array}{l}7 \text { day exposure, during: Nov } \\
\text { to Jan } 1995 \text { and June to } \\
\text { Aug } 1995\end{array}$ & $\begin{array}{l}\text { 40\% lower at } 20 \mathrm{~m} \text { vs } 3.5 \mathrm{~m} \text { (summer, read } \\
\text { from graph); no significant difference } \\
\text { during winter. Vertical profile, as part of a } \\
\text { larger spatial study, was based on one set of } \\
\text { measurements taken in both winter and } \\
\text { summer }\end{array}$ & $\begin{array}{l}\text { Monn et al. } \\
\text { (1997) }\end{array}$ \\
\hline London, UK & DT $2.5 \mathrm{~m}$ and at $18.5 \mathrm{~m}$ & $\begin{array}{l}\text { 'Back of } \\
\text { pavement' }\end{array}$ & $\begin{array}{l}1 \text { week exposure period } \\
\text { during Feb } 1995 \text { and } \\
\text { June } 1995\end{array}$ & $\begin{array}{l}\text { 15-30\% lower at } 18.5 \mathrm{~m} \text { vs } 2.5 \mathrm{~m} \text {. In } \\
\text { summer, there was evidence of a small } \\
\text { increase in concentration at } 7 \mathrm{~m} \text { vs } 2.5 \mathrm{~m} \text {. } \\
\text { Values read from graph. Findings based on } \\
\text { one set of measurement taken in both } \\
\text { winter and summer }\end{array}$ & $\begin{array}{l}\text { Laxen and } \\
\text { Noordally } \\
\text { (1987) }\end{array}$ \\
\hline Heidelberg & Chemiluminescence & $\begin{array}{l}\text { Test tower, } \\
60 \mathrm{~m} \\
\text { downwind } \\
\text { from a } \\
\text { motorway }\end{array}$ & $12 \mathrm{~h}$ & $\begin{array}{l}20 \% \text { lower at } 10 \mathrm{~m} \text { vs } 5 \mathrm{~m} \text { for a site } \\
\text { downwind of a motorway; and }<2 \% \text { lower } \\
\text { at } 10 \mathrm{~m} \text { vs } 5 \mathrm{~m} \text { for a site upwind of a } \\
\text { motorway (read from graph; findings based } \\
\text { time-integrated continuous measurements } \\
\text { over } 12 \mathrm{~h} \text { ) }\end{array}$ & $\begin{array}{l}\text { Kohler et al. } \\
\text { (2005) }\end{array}$ \\
\hline Singapore & $\begin{array}{l}\text { DT, ground level to } 50 \mathrm{~m} \\
\text { on high rise buildings } \\
30 \mathrm{~m} \text { downwind of an } \\
\text { expressway }\end{array}$ & $\begin{array}{l}\text { Building } \\
\text { façade, } \\
20 \mathrm{~m} \text { from } \\
\text { express- } \\
\text { way }\end{array}$ & $\begin{array}{l}5 \text { week exposure periods } \\
\text { during Dec to March and } \\
\text { June to Sept }\end{array}$ & $\begin{array}{l}12-16 \% \text { higher at } 17.5 \mathrm{~m} \text { vs ground level } \\
\text { (read from the graph). Based on profiles } \\
\text { presented for two buildings }\end{array}$ & $\begin{array}{l}\text { Cheong et al. } \\
\text { (2012) }\end{array}$ \\
\hline
\end{tabular}


did not show a significant difference. Moreover, upon analysis of sub-groups within the $<5 \mathrm{~m}$ data, Kenagy et al. (2016) found that the significance in differences between heights does not extend beyond $2 \mathrm{~m}$, which contradicts our results for site 1 , and the combined dataset, but is in agreement with our results from site 2 .

However, our findings for site 1 and the combined dataset, and those of Kenagy et al. (2016) for diffusion tubes $<5 \mathrm{~m}$ from the kerb, directly contradict a study published by the Scottish Government, who used a mobile road-located trolley to measure concentrations at $0.8 \mathrm{~m}$ and $1.68 \mathrm{~m}$. The Scottish Government study found that $\mathrm{NO}_{2}$ concentrations were $15 \%$ higher in adult breathing height compared with that in children's breathing height at busy junctions, though no significant difference was observed for low ambient concentrations (Scottish Government 2015). The discrepancy between studies is most likely explained by methodological differences, such as the siting of the monitor on the road, where the chemistry will be different. Also, the Scottish Government study used an electrochemical method (AQMesh) which has been shown to need additional correction to bring it in line with co-located measurements from reference monitors (Cordero et al. 2018). However, these contrasting findings do highlight a general difficulty in the literature about firmly establishing relationships between $\mathrm{NO}_{2}$ (and other pollutants) with height, and on setting guidance on the placement of diffusion tubes and other monitors.

\section{Public health implications}

Our study has shown that there is no significant difference in $\mathrm{NO}_{2}$ concentration between diffusion tubes placed at $1.7 \mathrm{~m}$ (adult breathing height) compared with that at $2.7 \mathrm{~m}$. Consequently, there is no evidence that the use of locations higher than adult breathing height by many municipal authorities in the UK is likely to lead to underreporting of $\mathrm{NO}_{2}$ concentrations with respect to the guideline values. This finding is important because UK government guidance allows local authorities considerable leeway in determining the height at which diffusion tubes are placed, so as to minimise theft and damage (Kenagy et al. 2016). The variability in practice across the UK is demonstrated by Table $\mathrm{S} 1$ in the supplementary material, which shows typical ranges of diffusion tube heights used by local authorities, as detailed in their Annual Status Reports (Progress Reports in Scotland and Wales), which are submitted to DEFRA as part of the LAQM process in the UK (DEFRA 2016).

However, our study has provided evidence to support previous literature observations (Kenagy et al. 2016) that the standard practice of locating diffusion tubes at heights either at or above adult breathing height in the UK may lead to an underestimation of the concentration of $\mathrm{NO}_{2}$ experienced by children, either walking or in prams and buggies. These concerns have been highlighted in the literature for nitrogen dioxide, particulate matter and other pollutants (Sharma and
Kumar 2018). In the present study, at site 1 , we found that $\mathrm{NO}_{2}$ concentrations over an 8-month period were $5.9 \%$ lower at the NCC standard diffusion tube height $(2.7 \mathrm{~m})$ compared with at children's breathing height $(0.7 \mathrm{~m})$. Moreover, we have shown that the zone in which these vertical concentration differences are significant may extend to at least $7 \mathrm{~m}$, which is considerably further than reported by Kenagy et al. (2016). These findings have clear public health implications as they indicate that children, in an urban setting and close to busy roadways, may be exposed to higher $\mathrm{NO}_{2}$ concentrations compared with those experienced by an adult in the same location. The health effects of air pollution are amplified in vulnerable groups such as young children, especially those with pre-existing medical conditions such as asthma (Esposito et al. 2014; Favarato et al. 2014). Young children are considered vulnerable because their organs and immune systems are still developing and are therefore more susceptible to the damaging effects of air pollution (Paulin and Hansel 2016).

To emphasise the potential influence of sampling height on LAQM in Newcastle upon Tyne, we have calculated the effect of placing diffusion tubes at heights of $0.7 \mathrm{~m}$ instead of $2.7 \mathrm{~m}$ across the city. We have assumed a $4.4 \%$ increase in $\mathrm{NO}_{2}$ at all diffusion tube locations (based on the percentage increase at both sites combined), though we acknowledge the many varying factors that influence vertical $\mathrm{NO}_{2}$ profiles, as already discussed. Table 4 shows that based on 2017 data (Newcastle City Council 2018), an extra five (out of 41) diffusion tube locations would exceed the $\mathrm{NO}_{2}$ annual mean objective of $40 \mathrm{mg} \mathrm{m}^{-3}$ and a further five sites would potentially be in exceedance of the $\mathrm{NO}_{2} 1$-h mean objective of $200 \mu \mathrm{g} \mathrm{m}^{-3}$, as they would exceed an annual mean of $60 \mathrm{\mu g} \mathrm{m}^{-3}$, which is accepted as being indicative of an exceedance of the 1-h guideline (DEFRA 2016; Laxen and Marner 2003). For data collected during 2018, the effect is smaller with only two additional diffusion tube locations exceeding the $40 \mu \mathrm{g} \mathrm{m}^{-3}$ guideline value and one location exceeding $60 \mu \mathrm{g} \mathrm{m}^{-3}$.

\section{Conclusions}

The passive monitoring of two roadside locations for 8 months along a heavily trafficked urban roadway in Newcastle upon Tyne (UK) found that $\mathrm{NO}_{2}$ concentrations at child breathing heights $(0.7 \mathrm{~m})$ were significantly different to those at adult breathing heights $(1.7 \mathrm{~m})$ and Newcastle City Council (NCC) 2017 sampling height $(2.7 \mathrm{~m})$. Paired $t$ test results showed that $\mathrm{NO}_{2}$ concentrations at child breathing heights were on average $4.71 \%$ and $7.12 \%$ lower at $2.7 \mathrm{~m}$ and $1.7 \mathrm{~m}$ respectively compared with that at $0.7 \mathrm{~m}$. Nevertheless, there was variability in the results, as when analysed separately, one of the sites did not show a significant difference. The monitoring was carried out at a greater distance from the road than with previous 
Table 4 Predicted change in the number of $\mathrm{NO}_{2}$ monitoring locations in Newcastle upon Tyne that breach the $40-\mu \mathrm{g} \mathrm{m}^{-3}$ annual guideline value. Also shown is the change in the number of locations that exceed
$60 \mu \mathrm{g} \mathrm{m}^{-3}$, which is indicative of a breach of the $200-\mu \mathrm{g} \mathrm{m}^{-3}$ hourly guideline value. Data is shown for both 2017 and 2018

\begin{tabular}{|c|c|c|c|c|c|c|}
\hline \multirow[t]{2}{*}{ Diffusion tube height } & \multicolumn{3}{|c|}{2017 ASR diffusion tube data } & \multicolumn{3}{|c|}{2018 ASR diffusion tube data } \\
\hline & Total & $N>40 \mu \mathrm{g} \mathrm{m}^{-3}$ & $N>60 \mu \mathrm{g} \mathrm{m}^{-3}$ & Total & $N>40 \mu \mathrm{g} \mathrm{m}^{-3}$ & $N>60 \mu \mathrm{g} \mathrm{m}^{-3}$ \\
\hline As reported (at $2.7 \mathrm{~m}$ in 2017 and $2.5 \mathrm{~m}$ in 2018 ) & 41 & 21 & 0 & 56 & 36 & 7 \\
\hline Calculated for $0.7 \mathrm{~m}$ & 41 & 26 & 4 & 56 & 38 & 8 \\
\hline
\end{tabular}

literature studies $(7 \mathrm{~m})$ and suggests that the zone in which there is a significantly varying vertical $\mathrm{NO}_{2}$ concentration profile at near-ground level has a greater extent than previously thought. Modelling carried out on diffusion tube data for Newcastle upon Tyne from 2017 and 2018 indicates that if diffusion tube monitoring was carried out at $0.7 \mathrm{~m}$, corresponding to the height of a child in a pram or buggy, there would be an increase in the number of monitoring locations that breached the $40 \mathrm{\mu g} \mathrm{m}^{-3}$ guideline value for $\mathrm{NO}_{2}$. Such a pattern is likely across all municipal authorities that carry out this type of monitoring, and so we should ask whether current practice adequately takes into account the most vulnerable receptors.

Acknowledgements We are grateful to Newcastle City Council for incorporating the two additional diffusion tube locations into their standard LAQM monitoring programme for the duration of the study.

Funding information This study was supported by Northumbria University and by Newcastle City Council (funded the diffusion tube analysis).

Data availability All data is available within the paper.

\section{Compliance with ethical standards}

Conflict of interest The authors declare that they have no conflict of interest.

Open Access This article is licensed under a Creative Commons Attribution 4.0 International License, which permits use, sharing, adaptation, distribution and reproduction in any medium or format, as long as you give appropriate credit to the original author(s) and the source, provide a link to the Creative Commons licence, and indicate if changes were made. The images or other third party material in this article are included in the article's Creative Commons licence, unless indicated otherwise in a credit line to the material. If material is not included in the article's Creative Commons licence and your intended use is not permitted by statutory regulation or exceeds the permitted use, you will need to obtain permission directly from the copyright holder. To view a copy of this licence, visit http://creativecommons.org/licenses/by/4.0/.

\section{References}

AEA Energy \& Environment (2008) Diffusion tubes for ambient NO2 monitoring: practical guidance for laboratories and users

Amato F, Pérez N, López M, Ripoll A, Alastuey A, Pandolfi M, Karanasiou A, Salmatonidis A, Padoan E, Frasca D, Marcoccia M, Viana M, Moreno T, Reche C, Martins V, Brines M, Minguillón MC, Ealo M, Rivas I, van Drooge B, Benavides J, Craviotto JM, Querol X (2019) Vertical and horizontal fall-off of black carbon and NO2 within urban blocks. Sci Total Environ 686:236-245. https:// doi.org/10.1016/j.scitotenv.2019.05.434

Atkinson RW, Butland BK, Anderson HR, Maynard RL (2018) Longterm concentrations of nitrogen dioxide and mortality: a metaanalysis of cohort studies. Epidemiology. 29:460-472. https://doi. org/10.1097/EDE.0000000000000847

Barratt B et al (2018) A dynamic three-dimensional air pollution exposure model for Hong Kong. Res Rep Health Eff Inst:1-65

Beckwith M, Bates E, Gillah A, Carslaw N (2019) NO2 hotspots: are we measuring in the right places? Atmos Environ: X 2:100025. https:// doi.org/10.1016/j.aeaoa.2019.100025

Borge R, Narros A, Artínano B, Yagüe C, Gómez-Moreno FJ, de la Paz D, Román-Cascón C, Díaz E, Maqueda G, Sastre M, Quaassdorff C, Dimitroulopoulou C, Vardoulakis S (2016) Assessment of microscale spatio-temporal variation of air pollution at an urban hotspot in Madrid (Spain) through an extensive field campaign. Atmos Environ 140:432-445. https://doi.org/10.1016/j.atmosenv.2016.06. 020

Carslaw DC, Farren NJ, Vaughan AR, Drysdale WS, Young S, Lee JD (2019) The diminishing importance of nitrogen dioxide emissions from road vehicle exhaust. Atmos Environ-X 1:100002. https://doi. org/10.1016/j.aeaoa.2018.100002

Cheong K, Tham K, Balasubramanian R, Kalaiarasan M (2012) Vertical distribution of $\mathrm{NO} 2$ in an urban area: exposure risk assessment in children. J Civil Environ Eng 2:1-6. https://oi.org/10.1016/j.aeaoa. 2019.100025

Clapp LJ, Jenkin ME (2001) Analysis of the relationship between ambient levels of $\mathrm{O} 3, \mathrm{NO} 2$ and $\mathrm{NO}$ as a function of $\mathrm{NO}_{x}$ in the UK. Atmos Environ 35:6391-6405. https://doi.org/10.1016/S13522310(01)00378-8

Committee on the Medical Effects of Air Pollutants (2018) Associations of long-term average concentrations of nitrogen dioxide with mortality. https://www.gov.uk/government/publications/nitrogendioxide-effects-on-mortality. Accessed 9th Jan 2020

Cordero JM, Borge R, Narros A (2018) Using statistical methods to carry out in field calibrations of low cost air quality sensors. Sensor Actuat B-Chem 267:245-254. https://doi.org/10.1016/j.snb.2018.04.021

DEFRA (2016) Local air quality management: technical guidance LAQM.TG(16). London

DEFRA (2019a) Clean air strategy 2019, London

DEFRA (2019b) Diffusion tube data entry system. https://laqm.defra. gov.uk/diffusion-tubes/data-entry.html. Accessed Jun 2020 
Department for Transport (2020) Road traffic statistics. https://roadtraffic. dft.gov.uk/\#6/55.254/-6.053/basemap-regions-countpoints. Accessed Jun 2020

Eeftens M, Odabasi D, Fluckiger B, Davey M, Ineichen A, Feigenwinter C, Tsai MY (2019) Modelling the vertical gradient of nitrogen dioxide in an urban area. Sci Total Environ 650:452-458. https://doi. org/10.1016/j.scitotenv.2018.09.039

Esposito S, Galeone C, Lelii M, Longhi B, Ascolese B, Senatore L, Prada E, Montinaro V, Malerba S, Patria MF, Principi N (2014) Impact of air pollution on respiratory diseases in children with recurrent wheezing or asthma. BMC Pulm Med 14:130. https://doi.org/10. 1186/1471-2466-14-130

Favarato G, Anderson HR, Atkinson R, Fuller G, Mills I, Walton H (2014) Traffic-related pollution and asthma prevalence in children. Quantification of associations with nitrogen dioxide. Air Qual Atmos Health 7:459-466. https://doi.org/10.1007/s11869-0140265-8

Gaffin JM, Hauptman M, Petty CR, Sheehan WJ, Lai PS, Wolfson JM, Gold DR, Coull BA, Koutrakis P, Phipatanakul W (2018) Nitrogen dioxide exposure in school classrooms of inner-city children with asthma. J Allergy Clin Immunol 141:2249-2255.e2242. https://doi. org/10.1016/j.jaci.2017.08.028

Guerriero C, Chatzidiakou L, Cairns J, Mumovic D (2016) The economic benefits of reducing the levels of nitrogen dioxide (NO2) near primary schools: the case of London. J Environ Manag 181:615-622. https://doi.org/10.1016/j.jenvman.2016.06.039

Hazenkamp-von Arx ME et al (2004) PM2. 5 and NO2 assessment in 21 European study centres of ECRHS II: annual means and seasonal differences. Atmos Environ 38:1943-1953. https://doi.org/10.1016/ j.atmosenv.2004.01.016

Heal MR, Laxen DPH, Marner B (2019) Biases in the measurement of ambient nitrogen dioxide (NO2) by Palmes passive diffusion tube: a review of current understanding. Atmosphere-Basel. 10. https://doi. org/10.3390/atmos 10070357

Kenagy HS, Lin C, Wu H, Heal MR (2016) Greater nitrogen dioxide concentrations at child versus adult breathing heights close to urban main road kerbside. Air Qual Atmos Health 9:589-595. https://doi. org/10.1007/s11869-015-0370-3

Keuken MP, Roemer MGM, Zandveld P, Verbeek RP, Velders GJM (2012) Trends in primary NO2 and exhaust PM emissions from road traffic for the period 2000-2020 and implications for air quality and health in the Netherlands. Atmos Environ 54:313-319. https://doi. org/10.1016/j.atmosenv.2012.02.009

Kohler M, Corsmeier U, Vogt U, Vogel B (2005) Estimation of gaseous real-world traffic emissions downstream a motorway. Atmos Environ 39:5665-5684. https://doi.org/10.1016/j.atmosenv.2004. 09.088

Laxen D, Marner B (2003) Analysis of the relationship between 1-hour and annual mean nitrogen dioxide at UK roadside and kerbside monitoring sites. Available from Defra, 2006a and Defra

Laxen DPH, Noordally E (1987) Nitrogen-dioxide distribution in street canyons. Atmos Environ 21:1899-1903. https://doi.org/10.1016/ 0004-6981(87)90150-8

Mills IC, Atkinson RW, Anderson HR, Maynard RL, Strachan DP (2016) Distinguishing the associations between daily mortality and hospital admissions and nitrogen dioxide from those of particulate matter: a systematic review and meta-analysis. BMJ Open 6:e010751. https:// doi.org/10.1136/bmjopen-2015-010751
Monn C, Carabias V, Junker M, Waeber R, Karrer M, Wanner H-U (1997) Small-scale spatial variability of particulate matter $<10 \mu \mathrm{m}$ (PM10) and nitrogen dioxide. Atmos Environ 31:2243-2247. https://doi.org/10.1016/S1352-2310(97)00030-7

Newcastle City Council (2018) 2018 Air quality annual status report. https://www.newcastle.gov.uk/services/environment-and-waste/ environmental-health-and-pollution/air-pollution/air-quality. Accessed Jun 2020

Newcastle City Council (2019) 2019 Air quality annual status report. https://www.newcastle.gov.uk/services/environment-and-waste/ environmental-health-and-pollution/air-pollution/air-quality. Accessed Jun 2020

Pannullo F, Lee D, Waclawski E, Leyland AH (2015) Improving spatial nitrogen dioxide prediction using diffusion tubes: a case study in West Central Scotland. Atmos Environ 118:227-235. https://doi. org/10.1016/j.atmosenv.2015.08.009

Paulin L, Hansel N (2016) Particulate air pollution and impaired lung function. F1000Res 5. https://doi.org/10.12688/f1000research. 7108.1

Rivas I, Donaire-Gonzalez D, Bouso L, Esnaola M, Pandolfi M, de Castro M, Viana M, Àlvarez-Pedrerol M, Nieuwenhuijsen M, Alastuey A, Sunyer J, Querol X (2016) Spatiotemporally resolved black carbon concentration, schoolchildren's exposure and dose in Barcelona. Indoor Air 26:391-402. https://doi.org/10.1111/ina. 12214

Sajani SZ et al (2018) Vertical variation of PM2.5 mass and chemical composition, particle size distribution, $\mathrm{NO} 2$, and BTEX at a high rise building. Environ Pollut 235:339-349. https://doi.org/10.1016/ j.envpol.2017.12.090

Salonen H, Salthammer T, Morawska L (2019) Human exposure to NO2 in school and office indoor environments. Environ Int 130:104887. https://doi.org/10.1016/j.envint.2019.05.081

Scottish Government (2015) Air quality study: assessing variations in roadside air quality with sampling height: a mobile air quality monitoring study commissioned to assess variations in roadside air quality. https://www.gov.scot/publications/air-quality-study-scotlandassessing-variations-roadside-air-quality-sampling/pages $/ 1 /$. Accessed 26th May 2020

Sharma A, Kumar P (2018) A review of factors surrounding the air pollution exposure to in-pram babies and mitigation strategies. Environ Int 120:262-278. https://doi.org/10.1016/j.envint.2018.07. 038

Vardoulakis S, Solazzo E, Lumbreras J (2011) Intra-urban and street scale variability of BTEX, $\mathrm{NO} 2$ and $\mathrm{O} 3$ in Birmingham, $\mathrm{UK}$ : implications for exposure assessment. Atmos Environ 45:5069-5078. https://doi. org/10.1016/j.atmosenv.2011.06.038

WHO (2006) WHO air quality guidelines for particulate matter, ozone, nitrogen dioxide and sulfur dioxide - global update 2005 - summary of the risk assessment. Geneva

Yang B, Zhang KM, Xu WD, Zhang S, Batterman S, Baldauf RW, Deshmukh P, Snow R, Wu Y, Zhang Q, Li Z, Wu X (2018) Onroad chemical transformation as an important mechanism of $\mathrm{NO} 2$ formation. Environ Sci Technol 52:4574-4582. https://doi.org/10. 1021/acs.est. $7 b 05648$

Publisher's note Springer Nature remains neutral with regard to jurisdictional claims in published maps and institutional affiliations. 